\title{
Cytotoxicity of temporary resins for orthodontic miniscrew covering
}

\author{
Amanda Carneiro da Cunha ${ }^{1}$, Maria Teresa Villela Romanos ${ }^{2}$, Lincoln Issamu Nojima ${ }^{1}$ and Mariana Marquezan ${ }^{1,3,4 *}$ \\ ${ }^{1}$ Department of Pedodontics and Orthodontics, Universidade Federal do Rio de Janeiro, Rio de Janeiro, Brazil \\ ${ }^{2}$ Departament of Microbiology and Immunology, Universidade Federal do Rio de Janeiro, Rio de Janeiro, Brazil \\ ${ }^{3}$ Centro de Estudos Odontológicos Meridional, Passo Fundo, RS, Brazil \\ ${ }^{4}$ Centro Universitário Franciscano, Santa Maria, RS, Brazil \\ ${ }^{5}$ Brazilian Army Dentist, Santa Maria, Rio Grande do Sul, Brazil
}

\begin{abstract}
Introduction: The covering of orthodontic miniscrews (MS) with temporary resins can relieve the patient's discomfort and prevent soft tissue injuries. The direct contact with these tissues for prolonged periods justifies the need of biocompatibility tests. The aim of this study was to evaluate the cytotoxicity of light-polymerized temporary fillings used for MS covering.

Methods: Two types of light curing temporary resins, Bioplic (Biodinâmica, Ibiporã, Paraná, Brazil) and Top Comfort (FGM, Joinville, Santa Catarina, Brazil) were assessed for their cytotoxicity in L929 fibroblastic cells. Four groups were analyzed: two experimental groups and two control groups (cell control and positive control). After the incubation period, the cells were examined in an inverted microscope (E600 Nikon Eclipse, Japan) and cell viability was determined using the dye uptake method. The optical density was measured with a spectrophotometer (BioTekTM, Winooski, Vermont, USA). Intergroup comparisons were performed with ANOVA and Tukey tests.
\end{abstract}

Results: Top comfort groups revealed to be more toxic at $48 \mathrm{~h}(0.488 \pm 0.068), 72(0.519 \pm 0.101)$ and $7 \mathrm{~d}(0.248 \pm 0.102)(\mathrm{P}<0.05)$.

Conclusions: The resins evaluated presented differences in the toxic activity. Top comfort presented an extended period of cytotoxicity until one week of the study.

\section{Introduction}

The use of orthodontic miniscrews (MS) is increasingly common in the contemporary treatment planning due to the need of an efficient and controlled movement of the teeth, especially in cases of patients with periodontal disease, deficient dentition and those who are not compliant with treatment demands [1-3]. The risks concerning the use of miniscrews includes complications during the insertion and removal procedures, problems in the loading process and soft tissue injury, such as aphtous ulceration, inflammation and infection [4].

The simple use of a wax pellet, separating elastic or a healing abutment can prevent the discomfort caused by traumatic lesions [4]. Recently, Marquezan et al. presented the covering of the miniscrew head with a temporary resin as an alternative to prevent these injuries (Figure 1) [5]. The direct contact with organic tissues for prolonged periods justifies the need of biocompatibility studies to investigate de
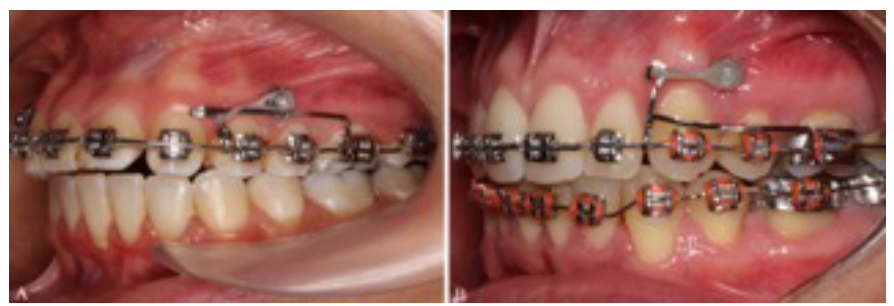

Figure 1. Clinical use of temporary resins for miniscrew coverage. A: Bioplic; B: Top Comfort. safety of using the orthodontic appliances, [6,7] including metal alloys, [7-10] elastomeric ligatures $[11,12]$ and resin-based materials $[13,14]$.

The biocompatibility of resin composites is directly influenced by the amount and nature of organic substances released [15], derived from incomplete polymerization or degradation over the time $[16,17]$. Despite several studies have been carried out on orthodontic adhesives [18-20], there was little emphasis regarding the biocompatibility of temporary composites used for covering miniscrews. The aim of this study was to evaluate the cytotoxicity of light-polymerized temporary fillings used for orthodontic miniscrew covering.

\section{Material and methods}

\section{Sample}

Two types of light curing temporary resins, used for covering of orthodontic MS - Bioplic (Biodinâmica, Ibiporã, Paraná, Brazil) and

Correspondence to: Mariana Marquezan, Department of Pedodontics and Orthodontics, Universidade Federal do Rio de Janeiro (UFRJ), Avenida Professor Rodolpho Paulo Rocco, 325, Ilha do Fundão, Rio de Janeiro, RJ, Brazil, Tel: 5521-2590-2727, Fax: 55-21-2590-9771; E-mail: marianamarquezan@gmail.com

Keywords: Biocompatibility testing, composite resins, orthodontic anchorage procedures

Received: June 05, 2015; Accepted: July 13, 2015; Published: July 16, 2015 
Top Comfort (FGM, Joinville, Santa Catarina, Brazil) (Table 1) - were selected for the assessment of their cytotoxicity.

The experimental groups, with three samples each, were divided based on the type of resin evaluated: group A - Bioplic and group B - Top comfort. As the test was carried out in triplicate, there were, in total, 9 values for each group. All the resins used in the study were in sealed packages and obtained from the same product lot.

\section{Sample preparation}

For the sample preparation, the materials used were previously sterilized in autoclave and with ultra-violet light exposure for 1 hour. The higher viscosity and consistency of the Bioplic resin enabled the removal of the material with a tooth sculpture tool. However, due to the fluid nature of the Top comfort resin, the material was transferred from the tip of the material tube to a tooth probe. This technique enabled the removal of similar quantities of both materials.

According to the manufacturer's instructions, the photopolymerization (DB 685 - Dabi Atlante, Ribeirão Preto, SP, Brazil) of Bioplic lasted 40 seconds and Top Comfort 30 seconds. After the preparation, all the samples were transferred to a 24 -well plate containing MEM for cytotoxic evaluation.

\section{Cell culture}

Mouse L929 fibroblasts lineage cells (American Type Culture Collection - ATCC, Rockville, MD, USA) were selected and cultivated in Eagle's minimum essential medium (MEM) (Cultilab, Campinas, Brazil) with $2 \mathrm{mM}$ of L-glutamine (Sigma, St.Louis, Missouri, USA), 50 $\mu \mathrm{g} / \mathrm{mL}$ of gentamicin (Schering Plough, Kenilworth, New Jersey, USA), $2.5 \mu \mathrm{g} / \mathrm{mL}$ of fungizone (Bristol-Myers-Squib, New York, USA), 0.25 $\mathrm{mM}$ of sodium bicarbonate solution (Merck, Darmstadt, Germany), $10 \mathrm{mM}$ of HEPES (Sigma, St. Louis, Missouri, USA), and $10 \%$ of foetal bovine serum (FBS) (Cultilab, Campinas, SP, Brazil). Then, the cell culture medium was incubated for 24 hours at $37^{\circ} \mathrm{C}$ in a $5 \% \mathrm{CO}_{2}$ atmosphere.

\section{Cytotoxicity assessment}

The 24-well plate MEM was replaced with fresh medium for every 24 hours and after $0,24,48,72$ hours, 7, 14 and 21 days the supernatants were collected in triplicate for the toxicity analysis to L929 cells. For each evaluation, the supernatants were transferred to 96 -well plates with a single layer of L929 cells and maintained at $37^{\circ} \mathrm{C}$ for 24 hours in $5 \% \mathrm{CO}_{2}$ environment. In order to examine the cells reaction to extreme conditions, two extra groups were included: Group C (positive control) constituted of cells in contact with Tween 20 (Polyoxyethylenesorbitan monolaurate) and Group D (cell control), represented by cells not exposed to any material tested.

At the end of the incubation period, the L929 cells were examined in an inverted microscope (E600 Nikon Eclipse, Japan) for morphologic

Table 1. Composition of the resins tested with their respective manufacturers and manufacturing lot.

\begin{tabular}{|l|l|l|c|}
\hline Resin & Manufacture & Composition & Lot \\
\hline Bioplic & $\begin{array}{l}\text { Biodinâmica, } \\
\text { Ibiporã, Paraná, } \\
\text { Brazil }\end{array}$ & $\begin{array}{l}\text { bis-GMA [21], dymethacrylate groups (40\%); } \\
\text { organic filler (25.18\%); silicium dioxide, catalysts } \\
\text { and sodium fluoride. }\end{array}$ & $706 / 14$ \\
\hline $\begin{array}{l}\text { Top } \\
\text { comfort }\end{array}$ & $\begin{array}{l}\text { FGM, Joinville, } \\
\text { Santa Catarina, } \\
\text { Brazil }\end{array}$ & $\begin{array}{l}\text { Methacrylic monomers (as bis-EMA, TEGDMA and } \\
\text { UDMA), stabilizer, camphorquinone, co-initiator, } \\
\text { pigments and inorganic fillers (40\%) of boro- } \\
\text { aluminium-silicate and silica nanoparticulate. }\end{array}$ & 270813 \\
\hline
\end{tabular}

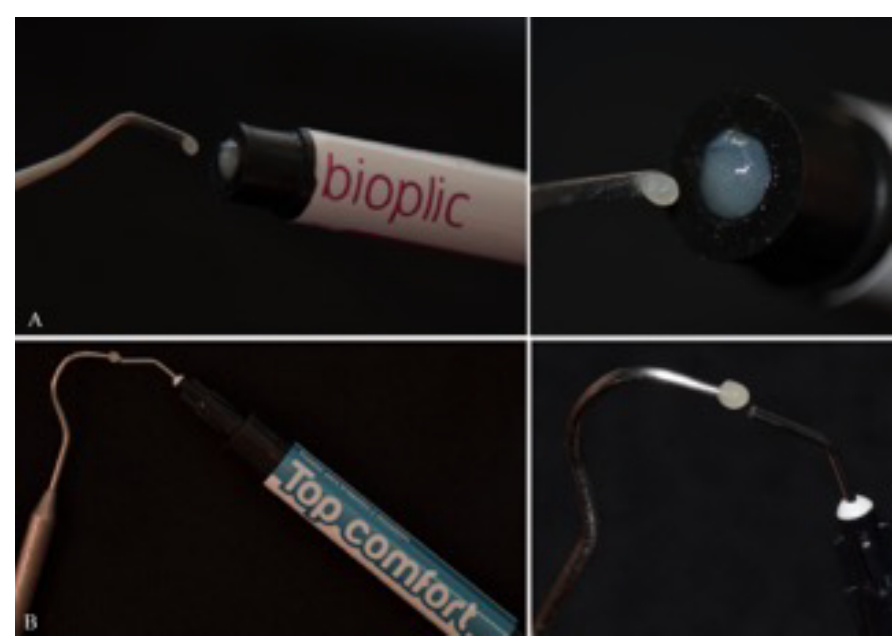

Figure 2. Samples of Bioplic (A) and Top Comfort (B), obtained through different techniques, but presenting similar dimensions.

evaluation and cell viability was determined using the method based on live cells incorporation of neutral-red dye described by Borenfreund and Puerner [22] with minor changes. Following a 24-hour incubation period, $100 \mu \mathrm{l}$ of $0.01 \%$ neutral-red staining solution (Sigma ${ }^{\mathrm{TM}}$, St. Louis, Missouri, USA) were incorporated to the medium of each well, except for the group C (positive control), which had $100 \mu \mathrm{l}$ of its medium replaced by $100 \mu \mathrm{l}$ of Tween 20 before the neutral-red deposition. Then, the plate was maintained for 3 hours at $37^{\circ} \mathrm{C}$ to allow the incorporation of the dye to the living cells. Then, the wells were washed with $200 \mu \mathrm{l}$ of PBS (130 mM NaCl; $2 \mathrm{mM} \mathrm{KCl} ; 6 \mathrm{mM} \mathrm{Na}_{2} \mathrm{HPO}_{4} 2 \mathrm{H}_{2} \mathrm{O} ; 1 \mathrm{mM} \mathrm{K}_{2} \mathrm{HPO}_{4}$, $\mathrm{pH}=7.2$ ) and fixed for 5 minutes with $100 \mu \mathrm{l}$ of $4 \%$ formaldehyde solution (Reagen ${ }^{\mathrm{TM}}$, Rio de Janeiro, Brazil), also in PBS. Finally, the dye was removed by adding $100 \mu \mathrm{l}$ of $1 \%$ acetic acid solution (Vetec, Rio de Janeiro, Brazil) with $50 \%$ methanol (Reagen ${ }^{\mathrm{TM}}$, Rio de Janeiro, Brazil) to the medium. After 20 minutes, the optical density was measured with a spectrophotometer (BioTek ${ }^{\mathrm{TM}}$, Winooski, Vermont, USA) at a wave length of $492 \mathrm{~nm}(\mu=492 \mathrm{~nm})$. The differences between the groups were visibly noticeable due to the color variation. The higher the level of the color shade (dye uptake) indicated a greater rate of viable cells as a result of lower cytotoxicity of the material. A comparison between these values and the analysis of morphology was performed to confirm the validity of results. The cell viability (in percentage) was calculated considering the ratio between the optical density of the group tested and the optical density of the control group (assuming that the control group is equivalent to $100 \%$ of viable cells).

\section{Statistical analysis}

Data were evaluated with the software SPSS (version 17, SPSS Inc., USA). The normality and homogeneity of variables were verified by Kolmogorov-Smirnov and Levene's tests. Intergroup comparisons were performed by ANOVA/Tukey post-hoc tests. The level of significance was $5 \%$.

\section{Results}

From the morphological evaluation of the extreme groups, group D showed the majority of spindle-shaped cells consistent with fibroblasts in normal development. However, in group C, the presence of rounded and granular cells indicated an environment of cellular apoptosis. Depending on the cytotoxicity level, the other groups presented the same tendency of the groups mentioned above. 
Table 2. Statistical analysis with mean, standard deviation and cell viability values of the experimental groups $(*$ SD indicates standard deviation **Different letters indicate statistical differences at $\alpha=.05$ ).

\begin{tabular}{|c|c|c|c|c|c|c|c|c|c|c|c|c|}
\hline \multirow[t]{2}{*}{ Groups } & \multirow[t]{2}{*}{ Mean } & \multirow[t]{2}{*}{ SD } & \multirow{2}{*}{$\begin{array}{c}\begin{array}{c}\text { Cell } \\
\text { viability }\end{array} \\
(\%)\end{array}$} & \multirow[t]{2}{*}{ Mean } & \multirow[t]{2}{*}{ SD } & \multirow{2}{*}{$\begin{array}{c}\begin{array}{c}\text { Cell } \\
\text { viability }\end{array} \\
(\%)\end{array}$} & \multirow[t]{2}{*}{ Mean } & \multirow[t]{2}{*}{ SD } & \multirow{2}{*}{$\begin{array}{c}\begin{array}{c}\text { Cell } \\
\text { viability }\end{array} \\
(\%)\end{array}$} & \multirow[t]{2}{*}{ Mean } & \multirow[t]{2}{*}{ SD } & \multirow{2}{*}{$\begin{array}{c}\text { Cell } \\
\text { viability } \\
(\%)\end{array}$} \\
\hline & & & & & & & & & & & & \\
\hline & & $\mathbf{O h}$ & & & $24 \mathrm{~h}$ & & & $48 \mathrm{~h}$ & & & $72 \mathrm{~h}$ & \\
\hline $\mathbf{A}$ & $0,393^{\mathrm{b}, \mathrm{c}}$ & 0,031 & 110,01 & $0,082^{\mathrm{a}}$ & 0,007 & 11,66 & $0,589^{c}$ & 0,035 & 87,91 & $0,659^{c}$ & 0,122 & 80,66 \\
\hline B & $0,425^{\mathrm{c}}$ & 0,039 & 120,05 & $0,356^{\mathrm{c}}$ & 0,135 & 50,64 & $0,488^{b}$ & 0,068 & 72,83 & $0,519^{b}$ & 0,101 & 63,52 \\
\hline C & $0,072^{\mathrm{a}}$ & 0,010 & 20,33 & $0,132^{\mathrm{a}, \mathrm{b}}$ & 0,002 & 18,77 & $0,073^{a}$ & 0,008 & 10,89 & $0,111^{\mathrm{a}}$ & 0,002 & 13,5 \\
\hline \multirow[t]{2}{*}{ D } & $0,354^{\mathrm{b}}$ & 0,028 & 100,00 & $0,703^{\mathrm{d}}$ & 0,053 & 100,00 & $0,670^{d}$ & 0,090 & 100,00 & $0,817^{\mathrm{d}}$ & 0,030 & 100,00 \\
\hline & & 7 days & & & 14 days & & & 21 days & & & & \\
\hline $\mathbf{A}$ & $0,327^{\mathrm{c}}$ & 0,021 & 80,94 & $0,626^{\mathrm{b}}$ & 0,021 & 80,77 & $0,407^{\mathrm{c}}$ & 0,030 & 73,33 & & & \\
\hline B & $0,248^{b}$ & 0,102 & 61,38 & $0,645^{\mathrm{b}, \mathrm{c}}$ & 0,017 & 83,22 & $0,388^{\mathrm{b}}$ & 0,022 & 69,90 & & & \\
\hline C & $0,087^{\mathrm{a}}$ & 0,007 & 21,53 & $0,249^{\mathrm{a}}$ & 0,030 & 32,1 & $0,323^{\mathrm{a}}$ & 0,168 & 58,19 & & & \\
\hline D & $0,404^{\mathrm{d}}$ & 0,014 & 100,00 & $0,775^{\mathrm{d}}$ & 0,111 & 100,00 & $0,555^{\mathrm{d}}$ & 0,005 & 100,00 & & & \\
\hline
\end{tabular}

The results of quantitative intergroup comparisons for the experimental groups are given in Table 2. Significant differences were found between the experimental and control groups, for all of the times assessed $(\mathrm{P}<0.05)$. At $0 \mathrm{~h}$, no group presented cytotoxic behavior, with the only exception for group C (positive control).

At $24 \mathrm{~h}$, group A $(0.082 \pm 0.007)$ exhibited severe toxicity and group B (0.356 \pm 0.135$)$ a moderate toxic activity (cell control: $0.703 \pm 0.053)$.

The Bioplic group (A) presented a satisfactory percentage of cell viability from $48 \mathrm{~h}$ to $21 \mathrm{~d}$ period. However, Top comfort group (B) revealed to be more toxic at $48 \mathrm{~h}(0.488 \pm 0.068), 72 \mathrm{~h}(0.519 \pm 0.101)$ and $7 \mathrm{~d}(0.248 \pm 0.102)(\mathrm{P}<0.05)$. At 14 and 21 days, both of the groups presented moderate percentage of cell viability with the exception of the group C (positive control)

\section{Discussion}

The biocompatibility assessment of temporary resins for orthodontic MS covering is justified by the proximity of these materials to the periodontal and soft tissues, such as gingiva and oral mucosa. The potential releasing of substances may induce to an inflammation process by the presence of water-soluble components into the oral cavity and the direct interaction with surrounding tissues [23]. Despite the fact that and in vitro toxic activity cannot imply the same for an in vivo application, the lack of cytotoxicity can support the clinical safety of a material. This issue is of utmost importance for the clinician that must be aware of potential risks of the orthodontic materials due to its prolonged time of permanence in the oral cavity [24].

The inherent standardization, simplicity and reproducibility of cytotoxicity tests [22] overcomes the disadvantages observed for animal experiments such as ethical restrictions, small sample sizes and poor levels of reproducibility [24]. The L929 fibroblasts model was chosen due to its similarity to gingival fibroblasts cytotoxic levels and excellent in-vitro reproducibility [25].

Bisphenol A diglycidyl dimethacrylate (bis-GMA) and triethylene glycol dimethacrylate (TEGDMA) are monomers that mainly constitute the orthodontic composites. Also, the matrix resin may be composed of other several monomers (bis-GMA and/or UDMA), co-monomers (EGDMA, DEGDMA, TEGDMA), aditives (camphorquinone, which is a photo-initiator), co-initiators (DMABEE, DEAEMA), inhibitors (BHT), photo-stabilizers, ultraviolet absorbers, and pigments [26,27].

The perinatal exposure to Bisphenol-A can have an effect on several mechanisms for body weight regulation and on the development and maturation of mechanisms important for homeostasis regulation [28]. TEGDMA is considered an important component once it decreases the viscosity of the matrix, thus allowing increased filler content [19]; however, a cytotoxic effect has been associated with this substance $[29,30]$. From our results study, the flow consistency of Top comfort resin, as well as it prolonged cytotoxic effect at $48 \mathrm{~h}, 72 \mathrm{~h}$ and 7 days, may be explained by the presence of TEGDMA in its matrix. It should be highlighted that as the details regarding the quantity of monomers, initiators and size of inorganic fillers were not supplied by both manufacturers, we were limited to establish any cause and effect relationship.

At $0 \mathrm{~h}$ (Zero) the levels of cell viability above the cell control were observed. These findings were related to the exposure of cells with a high number of passages to non-toxic concentrations of some metals such as titanium, aluminum and vanadium, which are the main components of orthodontic miniscrews [31,32]. All of the groups presented lower levels of cytotoxicity from the $14^{\text {th }}$ day of the study, which were considered to be acceptable, despite the significant differences from the cell control. The present study identified potential toxic activity for Top comfort resin that remained until one week of experiment suggesting further evaluation of the long-term effects of this material at low quantities, as it is used clinically. Considering that the levels of biocompatibility of both of resins were acceptable, but not ideal, further studies using different methodological assays for both of resins are needed.

\section{Conclusion}

- A severe toxic activity was observed by the Bioplic group and a moderate one by the Top comfort group at 24 hours of the study.

- Top comfort group presented an extended period of cytotoxicity for $48 \mathrm{~h}, 72 \mathrm{~h}$ and 7 days.

- From the $14^{\text {th }}$ day of the study both of the resins presented reasonable values of cell viability.

\section{Acknowledgements}

The authors acknowledge the financial support given by CAPES (Brazilian government) and FAPERJ (State of Rio de Janeiro government).

\section{References}

1. Costa A, Raffainl M, Melsen B (1998) Miniscrews as orthodontic anchorage: a preliminary report. Int J Adult Orthodon Orthognath Surg 13: 201-209. [Crossref]

2. Jambi S, Walsh T, Sandler J, Benson PE, Skeggs RM, et al. (2014) Reinforcement of 
anchorage during orthodontic brace treatment with implants or other surgical methods. Cochrane Database Syst Rev 8: CD005098. [Crossref]

3. Jain RK, Kumar SP, Manjula WS (2014) Comparison of intrusion effects on maxillary incisors among mini implant anchorage, j-hook headgear and utility arch. J Clin Diagn Res 8: ZC21-24. [Crossref]

4. Kravitz ND, Kusnoto B (2007) Risks and complications of orthodontic miniscrews. Am J Orthod Dentofacial Orthop 131: S43-51. [Crossref]

5. Marquezan M, de Freitas AO, Nojima LI (2012) Miniscrew covering: an alternative to prevent traumatic lesions. Am J Orthod Dentofacial Orthop 141: 242-244. [Crossref]

6. Grimsdottir MR, Hensten-Pettersen A, Kullmann A (1992) Cytotoxic effect of orthodontic appliances. Eur J Orthod 14: 47-53. [Crossref]

7. Locci P, Lilli C, Marinucci L, Calvitti M, Belcastro S, et al. (2000) In vitro cytotoxic effects of orthodontic appliances. J Biomed Mater Res 53: 560-567. [Crossref]

8. Pithon MM, dos Santos RL, Martins FO, Medeiros PJ, Romanos MTV (2010) Cytotoxicity of orthodontic mini-implants. Rev Clín Pesq Odontol 6:141-146.

9. Malkoç S, Öztürk F, Çörekçi B, Bozkurt BS, Hakki SS (2012) Real-time cell analysis of the cytotoxicity of orthodontic mini-implants on human gingival fibroblasts and mouse osteoblasts. Am J Orthod Dentofacial Orthop 141: 419-426. [Crossref]

10. Gonçalves TS, Menezes LM, Trindade C, Machado Mda S, Thomas P, et al. (2014) Cytotoxicity and genotoxicity of orthodontic bands with or without silver soldered joints. Mutat Res Genet Toxicol Environ Mutagen 762: 1-8. [Crossref]

11. dos Santos RL, Pithon MM, Martins FO, Romanos MT, de Oliveira Ruellas AC (2010) Evaluation of the cytotoxicity of latex and non-latex orthodontic separating elastics. Orthod Craniofac Res 13: 28-33. [Crossref]

12. Hanson M, Lobner D (2004) In vitro neuronal cytotoxicity of latex and nonlatex orthodontic elastics. Am J Orthod Dentofacial Orthop 126: 65-70. [Crossref]

13. dos Santos RL, Pithon MM, Martins FO, Romanos MT, Ruellas AC (2012) Evaluation of cytotoxicity and degree of conversion of glass ionomer cements reinforced with resin. Eur J Orthod 34: 362-366. [Crossref]

14. Shehata M, Durner J, Eldenez A, Van Landuyt K, Styllou P, et al. (2013) Cytotoxicity and induction of DNA double-strand breaks by components leached from dental composites in primary human gingival fibroblasts. Dent Mater 29: 971-979. [Crossref]

15. Geurtsen W (2000) Biocompatibility of resin-modified filling materials. Crit Rev Oral Biol Med 11: 333-355. [Crossref]

16. Geurtsen W (1998) Substances released from dental resin composites and glass ionomer cements. Eur J Oral Sci 106: 687-695. [Crossref]

17. Santerre JP, Shajii L, Leung BW (2001) Relation of dental composite formulations to their degradation and the release of hydrolyzed polymeric-resin-derived products. Crit Rev Oral Biol Med 12: 136-151. [Crossref]

18. Malkoc S, Corekci B, Ulker HE, Yalçin M, Sengün A (2010) Cytotoxic effects of orthodontic composites. Angle Orthod 80: 571-576. [Crossref]
19. Malkoc S, Corekci B, Botsali HE, Yalçin M, Sengun A (2010) Cytotoxic effects of resin-modified orthodontic band adhesives. Are they safe? Angle Orthod 80: 890-895. [Crossref]

20. Pithon MM, dos Santos RL, Martins FO, Romanos MTV, Araújo MTS (2010) Evaluation of Cytotoxicity and Degree of Conversion of Orthodontic Adhesives over Different Time Periods. Materials Research 13: 165-169.

21. dos Santos GL, Beltrame AP, Triches TC, Ximenes-Filho M, Baptista D, et al. (2014) Analysis of microleakage of temporary restorative materials in primary teeth. J Indian Soc Pedod Prev Dent 32: 130-134. [Crossref]

22. Borefreund E, Puerner A (1984) A simple quantitative procedure using monolayer cultures for cytotoxic assays (HTD/NR90). Journal of Tissue Culture Methods 9: 7-9.

23. Huang TH, Tsai CY, Chen SL, Kao CT (2002) An evaluation of the cytotoxic effects of orthodontic bonding adhesives upon a primary human oral gingival fibroblast culture and a permanent, human oral cancer-cell line. J Biomed Mater Res 63: 814-821. [Crossref]

24. Jonke E, Franz A, Freudenthaler J, König F, Bantleon HP, et al. (2008) Cytotoxicity and shear bond strength of four orthodontic adhesive systems. Eur J Orthod 30: 495502. [Crossref]

25. Schedle A, Samorapoompichit P, Rausch-Fan XH, Franz A, Füreder W, et al. (1995) Response of L-929 fibroblasts, human gingival fibroblasts, and human tissue mast cells to various metal cations. J Dent Res 74: 1513-1520. [Crossref]

26. Ferracane JL1 (1995) Current trends in dental composites. Crit Rev Oral Biol Med 6 302-318. [Crossref]

27. Spahl W, Budzikiewicz H, Geurtsen W (1998) Determination of leachable components from four commercial dental composites by gas and liquid chromatography/mass spectrometry. J Dent 26: 137-145. [Crossref]

28. Rubin BS, Soto AM (2009) Bisphenol A: Perinatal exposure and body weight. Mol Cell Endocrinol 304: 55-62. [Crossref]

29. Geurtsen W, Lehmann F, Spahl W, Leyhausen G (1998) Cytotoxicity of 35 dental resin composite monomers/additives in permanent $3 \mathrm{~T} 3$ and three human primary fibroblast cultures. J Biomed Mater Res 41: 474-480. [Crossref]

30. Stanislawski L, Lefeuvre M, Bourd K, Soheili-Majd E, Goldberg M, et al. (2003) TEGDMA-induced toxicity in human fibroblasts is associated with early and drastic glutathione depletion with subsequent production of oxygen reactive species. $J$ Biomed Mater Res A 66: 476-482. [Crossref]

31. Wataha JC, Hanks CT, Sun Z (1994) Effect of cell line on in vitro metal ion cytotoxicity Dent Mater 10: 156-161. [Crossref]

32. Galeotti A, Uomo R, Spagnuolo G, Paduano S, Cimino R, et al. (2013) Effect of pH on in vitro biocompatibility of orthodontic miniscrew implants. Prog Orthod 14: 15. [Crossref]

Copyright: (C2015 da Cunha AC. This is an open-access article distributed under the terms of the Creative Commons Attribution License, which permits unrestricted use, distribution, and reproduction in any medium, provided the original author and source are credited. 